Int. J. Dev. Biol. 55: 419-429

doi: $10.1387 / \mathrm{ijdb} .103220 \mathrm{dl}$

\title{
The role of blood flow and microRNAs in blood vessel development
}

\author{
DONG LIU, JANNA KRUEGER and FERDINAND LE NOBLE* \\ Department of Angiogenesis and Cardiovascular Pathology, Max Delbrueck Center for Molecular Medicine (MDC), \\ Berlin, Germany
}

\begin{abstract}
The circulatory system is the first organ system that develops during embryogenesis, and is essential for embryo viability and survival. Crucial for developing a functional vasculature are the specification of arterial-venous identity in vessels and the formation of a hierarchical branched vascular network. Sprouting angiogenesis, intussusception, and flow driven remodeling events collectively contribute to establishing the vascular architecture. At the molecular level, arterialvenous identity and branching are regulated by genetically hardwired mechanisms involving Notch, vascular endothelial growth factor and neural guidance molecule signaling pathways, modulated by hemodynamic factors. MicroRNAs are small, non-coding RNAs that act as silencers to fine-tune the gene expression profile. MicroRNAs are known to influence cell fate decisions, and microRNA expression can be controlled by blood flow, thus placing microRNAs potentially at the center of the genetic cascades regulating vascular differentiation. In the present review, we summarize current progress regarding microRNA functions in blood vessel development with an emphasis on studies performed in zebrafish and mouse models.
\end{abstract}

KEY WORDS: microRNA, blood vessel, development, endothelial cell, smooth muscle cell

\section{Introduction}

The formation of a properly branched vascular system is critical for embryo development and survival. Two successive processes called vasculogenesis and angiogenesis, achieve blood vessel formation during embryonic development. Vasculogenesis is the in situ differentiation of angioblasts and endothelial cells from mesenchyme, and their coalescence into tubes of the primary vascular plexus. This process is responsible for the formation of the central axial vessels (including the dorsal aorta), and a meshwork of capillaries. Expansion of the primitive vascular system formed by vasculogenesis occurs through sprouting and intussusception angiogenesis. These distinct angiogenesis processes lead to the remodeling of the primary vascular plexus into a hierarchical vascular tree, consisting of branched arteries, capillaries, and branched veins. Genetic imprinting of arterial-venous identity in embryonic vessels involves Notch signaling (Lawson et al., 2002) counteracted by COUP-TFII, and is reviewed in more detail elsewhere (Gridley, 2007; Swift and Weinstein, 2009). It is established that arteries and veins express distinct molecular markers including neural guidance genes like ephrinB2 and Unc5B in arteries, and EphB4 and neuropilin-2 in veins.
Sprouting angiogenesis involves the budding, and extension of new segments from preexisting vessels, that grow into previously avascular areas. The main driving forces for this process are gradients of vascular endothelial growth factor (VEGF) and hypoxia (Ruhrberg et al., 2002). It is now established that the growing angiogenic sprout consists of genetically distinct cell populations, the so-called endothelial tip and stalk cells (De Smet et al., 2009; Gerhardt et al., 2003). Tip cells display numerous filipodia that explore the local environment for guidance cues. The stalk cells can proliferate and form the lumen of the expanding sprout. The molecular key-players involved in tip-stalk cell differentiation include Notch-delta like 4 signaling (Hellstrom et al., 2007; Phng et al., 2009; Siekmann and Lawson, 2007; Suchting et al., 2007), VEGF receptor signaling (Chappell et al., 2009; Covassin et al., 2006; Tammela et al., 2008), as well as neural guidance gene receptors

\footnotetext{
Abbreviations used in this paper: 3' UTR, 3' un-translated region; CAD, coronary artery disease; COUP-TFII, chicken ovalbumin upstream promoter transcription factor 2; CTGF, connective tissue growth factor; GAX, growth arrest-specific homeobox; HIF- $1 \alpha$, hypoxia inducible factor- $1 \alpha$; HUVEC, human umbilical vein endothelial cell; miRNA, microRNA; MMVEC, myocardial microvascular endothelial cell; SMC, smooth muscle cells; VEGF, vascular endothelial growth factor.
}

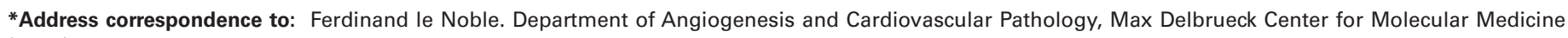
(MDC), Robert Roessle Strasse 10, D13125, Berlin, Germany. Fax: +49 30-9406-3850. e-mail: lenoble@mdc-berlin.de 
(Larrivee et al., 2009) that contribute to guidance and positioning of growing sprouts. The molecular processes governing sprout differentiation and vessel guidance will be discussed in more detail by Anne Eichmann, in this issue.

After the start of blood flow, the primitive vascular plexus shows a high degree of plasticity. Vessels with high flow widen, blood vessels with low flow regress, and some vessel segments are disconnected and reused to fashion growth of other vascular compartments (Buschmann et al., 2010; le Noble et al., 2004). While blood vessels with high blood flow in general appear to have less or no endothelial tip cells, increasing blood flow associates with the induction of splitting angiogenesis, also referred to as intussusception (Djonov et al., 2003; Djonov et al., 2000). This process contributes to increasing capillary number, adjustment of vessel branching angles in response to blood flow, and molding out small arterioles and venules from the capillary plexus. For a more comprehensive overview on intussusception, we refer to the chapter by Valentin Djonov, in this issue. The importance of blood flow in regulating arterial-venous differentiation and vessel patterning was recently shown in series of studies using zebrafish, chicken embryo and mouse embryo (Buschmann et al., 2010; le Noble et al., 2004; Lucitti et al., 2007; Nicoli et al., 2010). In mouse and chicken embryo, lack of blood flow perfusion in the yolk sac vascular plexus, for example induced by ablating cardiac activity, results in impaired remodeling of arteries and veins from capillaries. Moreover, in the chicken embryo, exposing arteries to venous blood flow resulted in down-regulation of arterial maker genes including ephrinB2 and neuropilin-1, and emergence of venous markers, including neuropilin-2 and COUP-TFII, in previous arterial domains. Vice versa, veins exposed to arterial flow conditions lost venous markers and instead started to express arterial markers, suggesting that hemodynamic factors can modulate the expression of arterial-venous identity genes. Since mice mutant for such identity genes in general show vascular remodeling defects during early embryogenesis, blood flow may contribute to the maintenance of the expression of these genes allowing AV remodeling to proceed.

In $\mathrm{Mlc2}^{-/-}$mutant mice, which display a selective cardiac contractility defect impeding proper control of cardiac output, yolk sac remodelling does not occur (Lucitti et al., 2007). This could be attributed to the mechanical properties of the early blood, and not to the presence of circulation angiogenic factors or changes in oxygen carrying capacity (Lucitti et al., 2007). Using erythroblast trapping techniques and injection of high molecular weight synthetic sugars, it was demonstrated that the mechanical force, normally imparted by the flow of circulating erythrocytes, is necessary and sufficient to induce vessel remodelling in the yolk sac of early mouse embryo. In neuropilin-1 mutant mice, yolk sac perfusion is initiated, by subsequent arterial-venous network formation severely impaired, suggesting that active neuropilin-1 function is required for the transduction of mechanical forces exerted by blood flow into a remodelling response (Jones et al., 2008).

We recently addressed which hemodynamic signal exerted by blood flow could be responsible for the maintenance of identity genes in developing arteries of the chicken embryo yolk sac vascular plexus (Buschmann et al., 2010). We considered factors related to flow (shear stress), pressure (pressure related cyclic stretch of vessels), and oxygen. The best discrimination between arteries and veins was obtained by calculating the maximal pulsatile increase in shear rate relative to the time-averaged shear rate in the same vessel: the relative pulse slope index (RPSI). RPSI is significantly higher in arteries than veins. Experimentally lowering RPSI in preexisting arterioles resulted in loss of arterial markers and emergence of venous markers (Buschmann et al., 2010). In vitro, exposure to a pulsatile shear regime augmented arterial marker expression including hey/hes transcription factors and ephrinB2, compared to exposure to constant shear. During early embryogenesis, arterial pressures in the developing yolk sac vasculature are extremely low (about $2 \mathrm{mmHg}$ in arteries, less than $1 \mathrm{mmHg}$ in veins), and pressure induced cyclic stretch was limited to the aorta only. Although the role of pressure in vessel remodeling in the adult is well established, the low pressures in the embryonic system, as well as the small differences in pressure between arteries and veins, makes it unlikely that, at this stage of development, endothelial cells can sense an absolute threshold pressure value above which they start to express arterial marker genes. Hypoxia is known to stimulate the expression of arterial markers in endothelial (progenitor) cells in vitro. Surprisingly, exposing the developing embryo to global hypoxia, reduced arterial network formation in the yolk sac most likely due to a negative inotropic effect of hypoxia on cardiac activity (Tintu et al., 2009), resulting in reduced cardiac output and flow delivery to the vitelline circulation.

Besides modulating vessel identity, blood flow also contributes to shaping the global pattern of developing arterial-venous networks (le Noble et al., 2004). In the chicken embryo these flow induced morphological changes included 1) flow driven fusion of small calibre vessels into large tubes, a process accounting for the formation of the large vitelline arteries and veins, 2) selective disconnection of endothelial cells from the arterial system and reuse of these endothelial cells to fashion growth of the venous system, 3) shear stress driven guidance of lumenized vessel sprouts. Moreover, in response to changes in arterial blood flow distribution, we noted strong induction of intussusception aiding to patterning of arteries in the direction of the evoked blood flow distribution. Such unique plasticity of the arterial pattern in response to blood flow may be limited to early embryogenesis, and during later stages other cues derived from vascular smooth muscle cells and perivascular nerves clearly contribute to regulating vessel identity and patterning as well (Larrivee et al., 2009).

Although zebrafish embryos can make the major axial vessels like the aorta, and cardinal vein, as well as the segmental sprouts in the absence of perfusion, it was recently shown that blood flow is essential for inducing sprouting events in aortic arch involving activation of the shear stress sensitive gene kfl2, activating VEGF signalling (Nicoli et al., 2010). In addition, blood flow was shown to be important for the formation of an arterial collateral circulation, resulting in rerouting of blood flow around an aortic stenosis in gridlock mutant zebrafish (Gray et al., 2007). Besides blood flow, this response depended on circulating myeloid cells, but appeared independent of hypoxia or tissue ischemia.

While in the adult, the vasculature is in general in a quiescent stage, postnatal vascular development occurs in response to a variety of physiological and pathological conditions including tissue ischemia, tissue repair, tumor growth and reproductive functions (Carmeliet, 2003). A special type of vascular adaptation occurs after arterial occlusion (Schaper, 2009). In this case the occlusion provokes a redistribution of blood flow resulting in the formation of a collateral arterial network that bypasses the occlusion and delivers blood flow to the compromised regions. This "biologi- 
cal bypass" critically determines the clinical outcome in several ischemic cardiovascular diseases including stroke, heart infarct and peripheral ischemia (Schaper, 2009). It is established that arteriogenesis, the outward remodeling of preexisting arterioles (mainly in the proximal part of the network), and angiogenesis (mainly in the distal part of the network), contribute to restoring flow and oxygenation after an ischemic insult. Increased blood flow appears to be an essential trigger for the arteriogenesis response (Eitenmuller et al., 2006), while tissue ischemia associates with the magnitude of the angiogenic response. Interestingly, inhibition of the biogenesis of miRNAs results in a severely disturbed vascular adaptive response after arterial occlusion (Suarez et al., 2008). Given the regulatory roles of miRNAs in cell fate decisions, and cell cycle control, as well as the observation that flow can regulate miRNA expression, miRNAs are emerging as potentially important targets for therapeutic angiogenesis and arteriogenesis approaches.

\section{MiRNA structure and function}

MiRNAs are single-stranded, none coding, RNA molecules of 18-25 nucleotides in length. The first animal miRNA was described in 1993 by Lee and colleagues in the Victor Ambros lab as a regulator of developmental timing in Caenorhabditis elegans (Lee et al., 1993). It was not until 2001 that miRNAs were confirmed to be widespread in various plants and animals, including Caenorhabditis elegans, Danio rerio, Homo sapiens, and the plant Arabidopsis Thaliana (Lagos-Quintana et al., 2001; Lau et al., 2001; Lee and Ambros, 2001). While the mechanisms used by miRNAs to regulate gene expression remain under debate, it is at present generally accepted that the main function of miRNAs is in gene silencing. For that purpose, a miRNA is complementary to a part of one or more messenger RNAs (mRNAs). In animals, miRNAs are usually complementary to a site in the 3' UTR.

Experimental evidence showing the distinct roles of miRNAs in physiological and pathophysiologic processes is just emerging. It has become clear that miRNA play diverse roles in fundamental biological processes, such as cell proliferation, differentiation, growth, apoptosis, stress response, and tumorigenesis. In particular, miRNAs have been implicated in various aspects of animal development, such as neuronal, muscle and cardiovascular development (Kloosterman and Plasterk, 2006; Stefani and Slack, 2008).

In the present review, current progress regarding the understanding of miRNA role in blood vessel development is summarized. It appears that miRNAs and the signaling pathways involved in vascular development coordinate perfectly the formation of the complex structured arterial-venous vascular network, and increasing experimental evidence indicates that miRNAs play important roles in the regulation of gene expression in blood vessel development and angiogenesis related diseases.

\section{MiRNAdiscovery, biogenesis and fundamental function}

In 1993, Lee and Feinbaum discovered that C. elegans gene lin-4 did not code a protein but instead produced a pair of short RNA transcripts (Lee et al., 1993). The two small lin-4 transcripts of approximately 22 and 61 nucleotides were found to contain sequences complementary to a repeated sequence element in the 3' UTR of lin-14 mRNA, suggesting that lin-4 regulates lin-14 translation via an antisense RNA-RNAinteraction (Lee et al., 1993;
Wightman etal., 1993). But the term microRNAwas only introduced in 2001 when the abundance of these tiny regulatory RNAs was discovered and reported in a set of three articles (Lagos-Quintana et al., 2001; Lau et al., 2001; Lee and Ambros, 2001). At present, miRNAs have been confirmed in various animals, including $C$. elegans, zebrafish, chicken, mouse and human (Cheng et al., 2007; van Rooij et al., 2006).

MiRNAs can be encoded by independent genes which contain their own miRNA gene promoter and regulatory units, but also can be processed from a variety of different RNA species, including introns, exons, 3' UTRs of mRNAs, long non-coding RNAs, snoRNAs and transposons (Bartel, 2004; He et al., 2008; Saraiya and Wang, 2008). As much as around $40 \%$ of miRNA genes may lie in the introns of protein coding genes or even in exons (Rodriguez et al., 2004). These genes are usually in a sense orientation and as a consequence could be regulated together with their host genes (Baskerville and Bartel, 2005; Cai et al., 2004; Kim and Kim, 2007; Rodriguez et al., 2004; Weber, 2005).

MiRNA genes are usually transcribed by RNA polymerase II, but a small amount of miRNA can also be transcribed by RNA polymerase III, such as those from transfer RNA (tRNA) (Faller and Guo, 2008; Lee et al., 2004). The transcription products range from hundreds to thousands nucleotides in length which are much longer than the mature miRNAs. They are usually capped with a modified nucleotide at the 5' end and polyadenylated (Cai et al., 2004; Lee et al., 2004). Each primary transcript called a pri-miRNA is processed into a short stem-loop structure, which is named pre-miRNA. Afterwards, the pre-miRNA is exported from the nucleus to cytoplasm in a process involving the nucleocytoplasmic shuttle Exportin-5. Finally the hairpin is cleaved by the RNase III enzyme Dicer into a RNA duplex. Then one of the double strands is incorporated into the RNA-induced silencing complex (RISC), where by base pairing to the 3' UTR of its target mRNA, results in gene silencing.

The mechanisms used by miRNAs to regulate gene expression are still subject of debate. Indeed, increasing evidence indicates that miRNAs repress protein expression at several different levels: (a) Deadenylation followed by mRNA degradation; (b) compete for elF6/60S ribosomal subunits; (c) compete for the cap binding; (d) block mRNA circularization by deadenylation; (e) premature termination of translation (ribosome drop-off); (f) inhibition of translation elongation; and (g) co-translational protein degradation (Carthew and Sontheimer, 2009; Chekulaeva and Filipowicz, 2009; Eulalio et al., 2008). MicroRNAs might also silence their targets by sequestering mRNAs in discrete cytoplasmic foci known as mRNAprocessing bodies or $P$ bodies, which exclude the translation machinery (Eulalio et al., 2008). In addition, animal miRNAs can induce significant degradation of mRNA targets despite imperfect mRNA-miRNA base pairing (Behm-Ansmant et al., 2006; Giraldez et al., 2006).

It is estimated that about one-third of the genes are regulated by miRNAs. The complexity of miRNA-dependent gene expression is further extended by the fact that more than one miRNA can cooperatively bind to the same 3' UTR and that each miRNA can regulate hundreds of targets (Doench et al., 2003). Like transcription factors, miRNAs regulate diverse cellular pathways and are widely believed to regulate most biological processes in plants and animals, ranging from housekeeping functions to responses to environmental stress. Covering this vast body of work is beyond 
the scope of this article; the cited reviews provide valuable insight (Bartel and Chen, 2004; Stefani and Slack, 2008; Yekta et al., 2008). Both basic and clinical studies suggest that miRNAs are important regulators of cell differentiation, growth, proliferation and apoptosis (Ambros, 2004; Hwang and Mendell, 2006; Jovanovic and Hengartner, 2006). Therefore miRNAs could be pivotal regulators in normal development and physiology, as well as in disease development.

\section{MiRNA expression signature in blood vessels}

Tissue-specific expression manner is one important characteristic of miRNA expression. As a matter of fact, one miRNA may be highly expressed in one tissue but have no or low expression in other tissues (Lagos-Quintana et al., 2002). At present, the systematic profile of miRNAs expressed in endothelial cells and smooth muscle cells, of different anatomical locations, or angiogenic conditions, remains to be performed.

Recently, the expression of 360 human miRNAs was profiled using real-time PCR in HUVECs. But comparative analysis was performed for only 23 miRNAs (Bonauer et al., 2009). Polisino et al. performed a large-scale analysis of miRNA expression in HUVECs, and identified 27 highly expressed miRNAs (Poliseno et al., 2006). Tamia A. Harris et al. measured the expression of miRNA in endothelial cells using microarray. Total RNA from HUVECs was size fractionated, labeled with a fluorescent dye, and hybridized on a microarray chip. Of the 500 miRNA probes on the microarray chip, the 26 miRNA with the highest level of expression in HUVECs were identified. The most frequently expressed vascular miRNA is miR-126 (Harris et al., 2008).

To study the biological functions of miRNA in vascular disease, Ruirui Ji et al. determined the miRNAexpression in rat carotid arteries through miRNA microarray analysis (Ji et al., 2007). Overall, 140 miRNAs of the 180 (more than $70 \%$ ) arrayed were found with 49 being highly expressed. Currently, around 200 miRNAs were detected in human endothelial cells by different methods.

\section{Effects of interrupting miRNA biogenesis on vascular development}

Constitutive expression of Dicer and Drosha protein was noted in cytoplasm and nucleus of endothelial cells respectively by using immuno-cytochemistry and Western blot (Kuehbacher et al., 2007; Suarez et al., 2007). The importance of miRNAs in endothelial cell function and blood vessel development was discovered by disrupting the function of Dicer and Drosha, two RNase III enzymes required for miRNA biogenesis.

The depletion of Dicer using siRNA in endothelial cells altered several key regulators of endothelial cell biology and angiogenesis including growth factor receptors, chemokines, cytokines and several other angiogenesis related genes, such as Tie-1, Tie-2, Id3, eNOS, IL-8, ENG (Endoglin), AKT1 and VEGFR2. Genetic silencing of both Dicer and Drosha significantly reduced capillary sprouting and proliferation of endothelial cells. Knockdown of Dicer resulted in significant impairment of the cord forming activity under base conditions and after stimulation with serum or VEGF in HUVECs and EA.hy.926. In the in vivo matrigel plug assay, vessel like structures were significantly reduced in Matrigel plugs with Dicer knockdown HUVECs. In contrast, Drosha siRNA transfec- tion did not significantly affect sprouting angiogenesis of Matrigel plugs in vivo (Kuehbacher et al., 2007; Shilo et al., 2008; Suarez et al., 2007). In this case, the less dramatic effects of knockdown of Drosha, might be explained by the mirtrons- short hairpin introns that provide an alternative source for animal microRNA biogenesis and use the splicing machinery to bypass Drosha cleavage in initial maturation (Chan and Slack, 2007).

The complete loss of Dicer function results in profound developmental defects in both zebrafish and mouse. In zebrafish, strong expression of maternal dicer 1 mRNAand ubiquitous expression up to $2 \mathrm{dpf}$ has been detected through whole-mount in situ hybridizations. Target-selected inactivation of the dicer1 gene in zebrafish resulted in the miRNA accumulation being stopped after a few days and developmental arrest around day 10 (Wienholds et al., 2003). Maternal-zygotic dicer mutants that lack both maternal and zygotic Dicer undergo axis formation and differentiate multiple cell types but display abnormal morphogenesis during gastrulation, brain formation, somitogenesis and heart development. Endothelial and hematopoietic precursor cells were present as judged from the expression of the markers fli-1 and scl, but endocardial fli-1 expression was reduced and blood circulation disrupted in MZ-dicer mutants (Giraldez et al., 2005).

It was found in two independent studies that Dicer is essential for normal mouse development. Bernstein et al., reported that loss of Dicer1 leads to lethality in early development, with Dicer1-null embryos depleted of stem cells. At E7.5, a subset of Dicer mutant mice embryos appeared small and morphologically abnormal, although distinctions between the embryonic and extra-embryonic regions were recognizable. It was suggested that Dicer mutant mice was growth arrested before the body plan is configured during gastrulation (Bernstein et al., 2003). In another study, Dicer-ex1/2 homozygous embryos displayed a retarded phenotype and died between days 12.5 and 14.5 of gestation. Interestingly, it was found that blood vessel formation and maintenance in dicer-ex1/2 embryos and yolk sacs were severely compromised, suggesting a possible role for Dicer in angiogenesis. This finding was confirmed by the altered expression of Vegf, Flt1, Kdr, and Tie1 in the mutant embryos. Taken together, it was indicated that Dicer exerts its function on mouse embryonic angiogenesis probably through its role in the processing of miRNA that regulate the expression levels of some critical angiogenesis regulators in the cell (Yang et al., 2005).

To overcome the early lethality, a conditional Dicer mutant mouse was created by Harfe et al. using the Dicer conditional allele and transgenic mouse lines that express Cre in the limb mesoderm, they proved an initial characterization of the role that Dicer plays in vertebrate limb development (Harfe et al., 2005). Cardiac-specific deletion of Dicer leads to rapidly progressive dilated cardiomyopathy, heart failure, and postnatal lethality. It was also indicated in this report that expression level of several important proteins in heart was altered by loss of Dicer (Chen et al., 2008). To address the importance of endothelial-specific miRNAs in postnatal angiogenesis, Suárez $\mathrm{Y}$ et al. generated two mouse models that were homozygous for the conditional floxed Dicer allele and expressed Cre-recombinase under the regulation of Tie2 promoter or Tamoxifen (TMX)-inducible expressed Cre-recombinase under the regulation of vascular endothelial cadherin promoter to achieve specific inactivation of Dicer in endothelial cells. Through these models, it was shown that reduction of endothelial miRNAs by cell-specific inactivation of Dicer reduced postnatal angiogenic 
responses to a variety of stimuli, including exogenous VEGF, tumors, limb ischemia, and wound healing (Suarez et al., 2008). Deletion of Dicer in vascular smooth muscle (VSM) results in late embryonic lethality at embryonic day 16 to 17 , and associates with extensive internal hemorrhage. The loss of VSM Dicer results in dilated, thin-walled blood vessels caused by a reduction in cellular proliferation. In addition, blood vessels from VSM-deleted Dicer mice exhibited impaired contractility because of a loss of contractile proteins (Albinsson et al., 2010).

\section{Individual miRNAs in endothelial cell biology}

Various miRNAs are thought to be expressed in a tissue-specific manner and, thus, may play tissue-specific roles. Tissue specificity is a peculiar feature of miRNAs and may have relevance also during angiogenesis, where highly coordinated multi-step processes are required. Currently a number of miRNAs were identified to be expressed in endothelial cells, and involved in blood vessel development (Table 1).

Through in situ hybridization with LNA (locked-nucleic acid) probes, miRNA-126 was detected in blood vessel and heart of zebrafish (Wienholds et al., 2005). After that, several in vitro and in vivo experiments showed that miR-126 was also expressed in endothelial cells of mammals. It was found that in HUVECs the most frequently expressed miRNA was miR-126. Studying miR-126 expression in primary human endothelial cells and other cell lines, showed that endothelial cells from veins, arteries, skin, and brain all express miR-126. However, other cell lines such as vascular smooth muscle cells (VSMC) or leukocyte cell lines do not (Fish et al., 2008; Harris et al., 2008; Wang et al., 2008b). Up to date, miR-126 was shown to play several roles in endothelial cell biology and blood vessel development. Transfection of endothelial cells with an oligonucleotide that decreases miR-126 permits an

\section{TABLE 1}

\section{MicroRNAs IN ENDOTHELIAL CELL BIOLOGY}

\begin{tabular}{|c|c|c|c|}
\hline MicroRNA & Functions & Relevant targets & References \\
\hline miR-126 & $\begin{array}{l}\text { Maintain vascular integrity, } \\
\text { development; activate Vegf } \\
\text { signaling }\end{array}$ & $\begin{array}{l}\text { VCAM-1, SPRED1, } \\
\text { PIR3R2/p85-B, }\end{array}$ & $\begin{array}{l}\text { Fish et al., 2008, } \\
\text { Harris et al., 2008, } \\
\text { Nicoli et al., 2010, } \\
\text { van Solingen et al., 2009, } \\
\text { Wang et al., 2008b }\end{array}$ \\
\hline \multirow[t]{2}{*}{$\begin{array}{l}\text { miR-17-92 } \\
\text { cluster }\end{array}$} & $\begin{array}{l}\text { Induce tumor angiogenesis, } \\
\text { promote cell proliferation, } \\
\text { suppress apoptosis, }\end{array}$ & $\begin{array}{l}\text { Tsp1(miR-19), } \\
\text { CTGF(miR-19), }\end{array}$ & $\begin{array}{l}\text { Dews et al., 2006, } \\
\text { Mendell, 2008, } \\
\text { Olive et al., } 2010\end{array}$ \\
\hline & inhibit sprouting & Jak1 (MiR-17/20) & Doebele et al., 2010 \\
\hline miR-92a & $\begin{array}{l}\text { negative regulator of } \\
\text { growth of new blood } \\
\text { vessels }\end{array}$ & $\begin{array}{l}\text { the integrin subunit } \\
\text { alpha5 }\end{array}$ & Bonauer et al., 2009 \\
\hline $\mathrm{miR}-221 / 222$ & $\begin{array}{l}\text { inhibit the survival, } \\
\text { migration, and capillary } \\
\text { tube formation in EC }\end{array}$ & $\begin{array}{l}\text { c-Kit, SCF, eNOS(I } \\
\text { ndirect ) }\end{array}$ & $\begin{array}{l}\text { Minami et al., 2009, } \\
\text { Murohara et al., 1998, } \\
\text { Poliseno et al., 2006, } \\
\text { Suarez et al., } 2007\end{array}$ \\
\hline $\operatorname{miR}-210$ & $\begin{array}{l}\text { stimulate the formation of } \\
\text { capillary-like structures and } \\
\text { migration of ECs }\end{array}$ & $\begin{array}{l}\text { ephrin-A3, neuronal } \\
\text { pentraxin } 1, \mathrm{HIF}-1 \\
\text { alpha }\end{array}$ & $\begin{array}{l}\text { Fasanaro et al., } 2008, \\
\text { Ivan et al., 2008, } \\
\text { Pulkkinen et al., } 2008\end{array}$ \\
\hline miR-296 & $\begin{array}{l}\text { promoting angiogenesis in } \\
\text { tumors }\end{array}$ & HGS & $\begin{array}{l}\text { Hua et al., 2006, } \\
\text { Wurdinger et al., } 2008\end{array}$ \\
\hline miR-130a & $\begin{array}{l}\text { Promote angiogenesis in } \\
\text { vascular ECs }\end{array}$ & GAX and HOXA5 & Chen and Gorski, 2008 \\
\hline $\operatorname{miR}-378$ & $\begin{array}{l}\text { enhance cell survival, } \\
\text { tumor growth, and } \\
\text { angiogenesis }\end{array}$ & $\begin{array}{l}\text { Sufu and Fus-1, } \\
\text { VEGF }\end{array}$ & $\begin{array}{l}\text { Hua et al., 2006, } \\
\text { Lee et al., } 2007\end{array}$ \\
\hline miR-320 & impair angiogenesis & IGF-1 & Wang et al., 2009 \\
\hline
\end{tabular}

increase in TNF- $\alpha$-stimulated VCAM-1 expression. Conversely, overexpression of the precursor of miR-126 increases miR-126 levels and decreases VCAM-1 expression. In addition, decreasing endogenous miR-126 levels increases leukocyte adherence to endothelial cells (Harris et al., 2008; van Solingen et al., 2009). Knockdown of miR-126 in zebrafish resulted in loss of vascular integrity and hemorrhage during embryonic development. MiR-126 functioned in part by directly repressing negative regulators of the'VEGF pathway, including the sprouty-related protein SPRED1 and phosphoinositol-3 kinase regulatory subunit 2(PIR3R2/p85- $\beta$ ) (Fish et al., 2008). In mice, it was found that miR-126 originates from the Egfl7 pre-mRNA. Targeted deletion of miR-126 in mice causes leaky vessels, hemorrhaging and partial embryonic lethality, due to a loss of vascular integrity and defects in endothelial cell proliferation, migration and angiogenesis. MiR-126 enhances the proangiogenic actions of VEGF and FGF and promotes blood vessel formation by repressing the expression of Spred-1 (Wang et al., 2008b). In addition, miR-126 deletion inhibited VEGFdependent Akt signaling by depression of the $p 85 \beta$ subunit of PI3 kinase (Kuhnert et al., 2008). Moreover, according to the latest report, by using two-photon imaging of living zebrafish embryos, it was observed that flow is essential for angiogenesis during AA development requiring miR-126. It was shown that angiogenic sprouting of Aortic arch vessels requires a flow-induced genetic pathway in which the mechano-sensitive transcription factor klf2a induces expression of an endothelial-specific microRNA, miR-126, to activate VEGF signaling (Nicoli et al., 2010).

The miR-17-92 cluster is highly conserved in vertebrate evolution, and encodes miR-17, miR-18a, miR-19a, miR-20a, miR-19b-1 and miR-92a-1 within an 800 bp intronic region on chromosome13 (in Homo sapiens) (Olive et al., 2010). Interestingly, not only the sequence of each miRNA component is highly conserved across species; the organization of these miRNAs within the miR-17-92 family also exhibits a high level of conservation. The functional significance of this conservation is still unclear. It possibly reflects the evolutionary path through which gene duplications followed by subsequent loss of individual miRNA components shaped the formation of this polycistronic miRNA family (Olive et al., 2010). MiRNAs encoded by the miR-17-92 cluster and its paralogs are known to act as oncogenes. Expression of these miRNAs promotes cell proliferation, suppresses apoptosis of cancer cells, and induces tumor angiogenesis (Mendell, 2008). These findings on miR-17-92 indicate that miRNAs are integrated components of the molecular pathways that regulate tumor development and tumor maintenance (Olive et al., 2010). A potent tumor angiogenesis promoting activity has been attributed to the miR-17-92 cluster, which is significantly unregulated in Myc-induced tumors. VEGF levels were unaffected by Myc, but enhanced neovascularization correlated with down-regulation of anti-angiogenic thrombospondin-1 (Tsp1) and related proteins, such as CTGF. Both Tsp1 and CTGF are predicted targets for repression by the miR-17-92 miRNA cluster. In particular, miR-18 preferentially suppresses CTGF expression, whereas miR-19 targets the potent angiogenesis- inhibitor Tsp1 (Dews et al., 2006). In addition, over expression of c-myc leads to down regulation of HIF-1 $\alpha$ and induction of miR-17-92, the latter of which was reported to be a transcriptional activation activity, suggesting that the induction of miR-17-92 may play a role at least in part in c-myc-mediated repression of HIF-1 $\alpha$ (Taguchi et al., 2008). Moreover, Angelika et al., reported miR-17-92 cluster is 
highly expressed in human endothelial cells. Recent work reveals essential functions for these miRNAs not only in tumor angiogenesis but also during normal development of blood vessels. MiR-92a, a component of this cluster was recently identified as a negative regulator of growth of new blood vessels. Forced overexpression of miR-92a in endothelial cells blocked angiogenesis in vitro and in vivo with targeting mRNAs corresponding to several proangiogenic proteins, including the integrin subunit alpha5. In mouse models of limb ischemia and myocardial infarction, systemic administration of an antagomir designed to inhibit miR-92a led to increased blood vessel growth and functional recovery of damaged tissue (Bonauer et al., 2009). It was demonstrated that overexpression of miR-17, -18a, -19a and -20a significantly inhibited 3D spheroid sprouting in vitro, whereas inhibition of miR-17, -18a and -20a augmented endothelial cell (EC) sprout formation. Inhibition of miR-17 and miR-20a in vivo using antagomirs significantly increased the number of perfused vessels in matrigel plugs, whereas antagomirs that specifically target miR-18a and miR-19a were less effective. MiR-17/20 targets several pro-angiogenic genes, such as Janus kinase 1 (Jak1) (Doebele et al., 2010).

MiR-221 and miR-222 genes are located in close proximity on chromosome13.3. They were found to be expressed in but not confined to endothelial cells in several studies. It has been demonstrated that miR-221 and miR-222 affect c-Kit expression and the angiogenic properties of its ligand, stem cell factor (SCF). As a consequence, they inhibit the survival, migration, and capillary tube formation in HUVECs (Poliseno et al., 2006). Another study indicated that miR-221/222 regulates endothelial nitric oxide synthase protein (eNOS) levels after Dicer silencing, however miR-221/222 were not found to target the 3' UTR of eNOS. So, the regulation of eNOS by miR-221/222 is likely to be an indirect effect (Suarez et al., 2007). It is established that eNOS, also known as nitric oxide synthase 3 (NOS3), generates $\mathrm{NO}$ in blood vessels and is involved in regulating vascular formation and function in several aspects (Murohara et al., 1998). Interestingly, a study from Minami et al., suggests the physiological role of miR-221/222 is closely linked to the proliferation of endothelial cells. It was shown that levels of miR-221/222 were significantly higher in the CAD group than in the non-CAD group and levels of miR-221/222 were weakly negatively correlated with Endothelial progenitor cells (EPCs) number in the CAD group (Minami et al., 2009). Collectively, these reports suggest miR-221/222 play an antiangiogenic role in vitro, although the in vivo functions are undetermined.

MiR-210 overexpression in normoxicendothelial cells stimulated the formation of capillary-like structures on Matrigel and vascular endothelial growth factor-driven cell migration. Conversely, miR210 blockade via anti-miRNA transfection inhibited the formation of capillary-like structures stimulated by hypoxia and decreased cell migration in response to vascular endothelial growth factor. MiR-210 overexpression did not affect endothelial cell growth in both normoxia and hypoxia. HIF-1 $\alpha$ induced the expression of miR210 in endothelial cells (Ivan et al., 2008). However, anti-miR-210 transfection inhibited cell growth and induced apoptosis, in both normoxia and hypoxia. Ephrin-A3 was determined to be one relevant target of miR-210 in hypoxia since miR-210 was necessary and sufficient to down-regulate its expression. Moreover, luciferase reporter assays showed that Ephrin-A3 was a direct target of miR-210. In summary, miR-210 up-regulation is a crucial element of the endothelial cell response to hypoxia, affecting cell survival, migration, and differentiation (Fasanaro et al., 2008). An active form of the HIF- $1 \alpha$ induced the expression of miR-210, showing the involvement of the HIF-1 signaling pathway in miR-210 gene transcription. Furthermore, miR-210 was shown to bind to the predicted target sites of ephrin-A3 or neuronal pentraxin 1, causing repression in luciferase reporter activity (Pulkkinen et al., 2008).

MiR-130a is located on chromosome 11 and the expression of this miRNA was found to be rapidly up regulated under high serum culture conditions in endothelial cells in vitro. It has been shown that miR-130a regulates GAX expression and plays a big role in modulating GAX activity in endothelial cells. The homeobox gene GAX inhibits angiogenesis in vascular endothelial cells. Agenomewide search for other possible miR-130a binding sites revealed a miR-130a targeting site in the 3' UTR of the anti-angiogenic homeobox gene HOXA5, whose expression and anti-angiogenic activity are also inhibited by miR-130a. In conclusion, miR-130a is a regulator of the angiogenic phenotype of vascular endothelial cells largely through its ability to modulate the expression of GAX and HOXA5 (Chen and Gorski, 2008). Thomas Würdinger et al., reported a role for miR-296 in promoting angiogenesis in tumors. Growth factor-induced miR-296 contributes significantly to angiogenesis by directly targeting the hepatocyte growth factor-regulated tyrosine kinase substrate (HGS) mRNA, leading to decreased levels of HGS and thereby reducing HGS-mediated degradation of the growth factor receptors VEGFR2 and PDGFR $\beta$ (Hua et al., 2006; Wurdinger et al., 2008).

Previous studies have shown that miR-378 is expressed in a number of cancer cell lines (Jiang et al., 2005) and is involved in the expression of VEGF (Hua et al., 2006). It was suggested that miR-378 transfection enhanced cell survival, tumor growth, and angiogenesis through repression of the expression of two tumor suppressors, Sufu and Fus-1. The tumors formed by miR-378-transfected cells contained larger blood vessels than those formed by the vector-transfected cells. Although the number of blood vessels per unit field did not seem to increase, it is probable that the total number of blood vessels in the larger tumors had to be higher to allow expansion of the tumor. The formation of the large vessels may be important in facilitating such expansion. These results are in agreement with the previous studies that show that miR-378 binds to VEGF 3' UTR competing with miR-125a for the same seed region and promotes VEGF expression (Lee et al., 2007).

Up-regulation of miRNA-320 was observed in MMVEC from Goto-Kakizaki (GK) rats using real-time reverse transcriptionpolymerase chain reaction (RT-PCR). Transfection of a miR-320 inhibitor into MMVEC from GK rats confirmed that miR-320 impaired angiogenesis. The proliferation and migration of diabetic MMVEC improved after transfection with the miR-320 inhibitor. In addition, the miR-320 inhibitor significantly increased the expression of IGF-1 protein, but had no effect on the expression of IGF-1R. The results indicate that up-regulation of miR-320 in MMVEC from GK rats may be responsible for the inconsistency between the expression of IGF-1 protein and mRNA and therefore related to impaired angiogenesis in diabetes (Wang et al., 2009).

\section{Individual miRNAs in smooth muscle cell biology}

The vessel wall consists of two major cell types, endothelial and smooth muscle cells that closely interact with each other. Vascular smooth muscle cells form layers within the vessel wall, 
and by contracting or relaxing, control the blood pressure and organ perfusion. VSMCs are able to switch between a differentiated and a dedifferentiated state (Owens et al., 2004). Under normal physiologic conditions VSMCs are differentiated and contractile. In the presence of vascular injury and growth factors VSMCs can change their phenotype to a dedifferentiated state, and start to proliferate. Although the modulation of VSMC phenotype is believed to be essential for the repair of vascular injury, deregulation of this process can lead to pathologic changes in the vascular wall. Such remodeling of VSMCs is often observed in atherosclerotic lesions, after chronic exposure to high blood pressure, or other hemodynamic stress conditions. Therefore VSMC differentiation is a key cellular event in the pathogenesis of a variety of vascular diseases including arteriogenesis, atherosclerosis, restenosis and hypertension (Doran et al., 2008; Owens et al., 2004; Rzucidlo et al., 2007).

Recent reports demonstrated a crucial role for miRNAs in VSMC differentiation. MiR-143 and miR-145 are abundantly expressed in VSMCs of arteries (Cheng et al., 2009; Ji et al., 2007), and the heart (Boettger et al., 2009; Cordes et al., 2009). During postnatal development the expression in heart is down regulated. To highlight the importance of miR-143 and miR-145 in VSMCs, Boettger and colleagues generated a mouse mutant for the microRNA cluster miR-143/145. Analysis of homozygous miR-143/145 mutant mice revealed a decrease in contractile VSMCs, an increase in proliferative precursors and formation of neointimal lesions (Boettger et al., 2009). Contractile behavior in other organs including, the gastrointestinal motility was not affected. Closer characterization of the physiology of the mutant mice exhibits defects in the agonist-induced SMC contractility in arteries. Changes of the blood pressure were also observed in another study (Xin et al., 2009), and angiotensin I-converting enzyme (ACE), which is implied in promoting vasoconstriction and alteration of VSMC phenotype, by converting angiotensin-I into the vasoactive hormone angiotensin-II, was suggested to be a potential target. Comparison of healthy with injured murine carotid arteries showed a decreased expression of miR-143 and miR-145 in the diseased artery (Cordes et al., 2009). Moreover down-regulation of miR-145 in dedifferentiated cultured SMCs was found. Overexpression of miR-145 led to inhibition of PDGF-induced VSMC proliferation (Cheng et al., 2009). The vascular remodeling in response to injury was also tested in the miR-143/145-null mice from Xing. Ligation of the carotid artery of miR-145/-mice showed virtually no formation of neointima, whereas in $\mathrm{miR}-143^{-/-}$a reduced formation compared to wild type mice was observed (Xin et al., 2009).

At the molecular level it is postulated that miR-145 promotes binding of myocardin to serum response factor (SRF) and thereby enhancing the transcription of SMC differentiation genes. On the other hand miR-145/143 blocks the expression of Ets-like gene 1 (ELK-1) and Krüppel-like factor 4 (KLF4), transcription factors necessary for stimulating the SMC proliferation (Wang et al., 2008a; Yoshida et al., 2008). However, additional targets (KLF-4, KLF-5) and regulatory functions may exist (Boettger et al., 2009) (Nagai et al., 2005). Additional targets involved in VSMC phenotype switching, regulation of actin polymerization and cell migration were identified using TargetScan and PicTar prediction algorithms (Xin et al., 2009) but remain to be validated in vivo (Xin et al., 2009). The potential targets for miR-143 and miR-145 are listed in Table 2.

Rat carotid arteries express miR-221 and miR-222 in the vascular wall (Poliseno et al., 2006). Microarray analysis revealed an upregulation of miR-221 and miR-222 in vessel walls with neointimal lesion formation (Ji et al., 2007). This up-regulation of miR-221 and miR-222 was further confirmed by qRT-PCR of rat carotid arteries after angioplasty in vivo. In addition, cultured proliferative VSMCs stimulated by PDGF or serum showed an increased expression of miR-221 and miR-222 (Lin et al., 2009). A study by Davis and colleagues (Davis et al., 2009) demonstrated an induction of miR-221 upon PDGF treatment in human primary pulmonary artery smooth muscle cells (PASMCs). The expression of miR-222 was weakly inhibited after PDGF treatment in PASMCs, suggesting that miR-221 and miR-222 are differentially regulated by PDGF in PASMC (Davis et al., 2009). Knockdown of miR-221 and miR-222 with antisense oligonucleotides resulted in decreased VSMC proliferation in vitro and in vivo, suggesting that miR-221 and miR-222 control VSMC proliferation (Lin et al., 2009).

MiR-221 and miR-222 share the same seed and appear to have identical targets and similar functions. Computational analysis predicted the potential targets p27 (Kip1) and p57 (Kip2) (Felicetti et al., 2008; Fornari et al., 2008; Galardi et al., 2007; le Sage et al., 2007; Visone et al., 2007). Gain-of-function and loss-of-function approaches confirmed both genes as targets for miR-221 and miR-222. In proliferative VSMCs, p27 (Kip1) and p57 (Kip2) were down regulated and therefore likely involved in the miR-221 and miR-222 mediated effect on VSMC proliferation (Liu et al., 2009). However, the partially inhibition of cell proliferation in p27 (Kip1) and p57 (Kip2) depleted cells indicates a possible role for other unidentified gene targets. Targets for miR-221 include c-kit and p27 (Felli et al., 2005; Fornari et al., 2008; Galardi et al., 2007; le Sage et al., 2007; Visone et al., 2007). C-kit causes inhibition of SMC-specific gene transcription by reducing the expression of myocardin, whereas p27Kip1 promotes cell proliferation upon vascular injury (Chen et al., 1997). It is postulated that the miR221-p27Kip1 axis might play a role in neointima formation after vascular injury (Liu et al., 2009).

MiR-21 is expressed in vascular smooth muscle cells, as well as endothelium, cardiomyocytes and fibroblasts (Cheng et al., 2007; Ji et al., 2007; Roy et al., 2009; Suarez et al., 2007). MiR-21 appears to play a crucial role in vascular adaptation in response to reactive

TABLE 2

\section{MicroRNAs IN SMOOTH MUSCLE CELL BIOLOGY}

\begin{tabular}{|c|c|c|c|}
\hline MicroRNA & Functions & Relevant targets & References \\
\hline \multirow[t]{3}{*}{ miR-145 } & $\begin{array}{l}\text { Promote contractile } \\
\text { phenotype of VSMC }\end{array}$ & KLF4, Camklld, KLF5 & $\begin{array}{l}\text { Cheng et al., 2009, } \\
\text { Cordes et al., } 2009\end{array}$ \\
\hline & $\begin{array}{l}\text { Modulate actin dynamics } \\
\text { and cytoskeletal assembly }\end{array}$ & $\begin{array}{l}\text { zinc finger proteins, KLF4, } \\
\text { KLF5, Srgap1, Srgap2, Add3, } \\
\text { Ssh2 phophatase, MRTF- }\end{array}$ & $\begin{array}{l}\text { Boettger et al., 2009, } \\
\text { Xin, et al., } 2009\end{array}$ \\
\hline & & B , Argagp12, Tpm4, Ace & \\
\hline \multirow[t]{2}{*}{$\operatorname{miR}-143$} & $\begin{array}{l}\text { Promote contractile } \\
\text { phenotype of VSMC }\end{array}$ & ELK1 & Cordes et al., 2009 \\
\hline & $\begin{array}{l}\text { Modulate actin dynamics } \\
\text { and cytoskeletal assembly }\end{array}$ & $\begin{array}{l}\text { zinc finger proteins, KLF4, } \\
\text { KLF5, Srgap1, Srgap2, Add3, } \\
\text { Ssh2 phophatase, MRTF-B, } \\
\text { Argagp12, Tpm4, Ace }\end{array}$ & $\begin{array}{l}\text { Boettger et al., 2009, } \\
\text { Xin, et al., } 2009\end{array}$ \\
\hline miR-221 & $\begin{array}{l}\text { Promote proliferative } \\
\text { phenotype of VSMC }\end{array}$ & p27(Kip2), c-Kit, p57 (Kip2) & $\begin{array}{l}\text { Davis et al., } 2008 \text {, } \\
\text { Liu et al., } 2009\end{array}$ \\
\hline miR-222 & $\begin{array}{l}\text { Promote proliferative } \\
\text { phenotype of VSMC }\end{array}$ & p27 (Kip1) and p57 (Kip2) & Liu et al., 2009 \\
\hline $\operatorname{miR}-21$ & $\begin{array}{l}\text { Protective effect on VSMC } \\
\text { necrosis }\end{array}$ & $\begin{array}{l}\text { programmed cell death } 4 \\
\text { (PDCD4), phosphatase and } \\
\text { tensin homology deleted from } \\
\text { chromosome } 10 \text { (PTEN) }\end{array}$ & $\begin{array}{l}\text { Ji et al., } 2007, \\
\text { Lin et al., } 2009\end{array}$ \\
\hline
\end{tabular}


oxygen species (ROS). It is well established that ROS play a central role in a variety of vascular disorders including atherosclerosis (Vandenbroucke et al., 2008). In line with this, hemodynamic stress conditions, as well as balloon denudation in arteries, is associated with increased expression of miR-21 (Cordes et al., 2009; Ji et al., 2007). Knockdown of miR-21 in these injured arteries inhibited neointimal lesion formation (Ji et al., 2007). In vitro, inhibition of miR-21 increased VSMC apoptosis, and decreased proliferation. In line with a regulatory role in adaptation to ROS, inhibition of miR-21 in $\mathrm{H}_{2} \mathrm{O}_{2}$ induced VSMCs revealed increased apoptosis and cell death, whereas overexpression of miR-21 resulted in reduced apoptosis and cell survival.

Computational analysis indicated that programmed cell death 4 (PDCD4) is a potential target gene of miR-21. PDCD4 is involved in the regulation of the apoptosis of VSMCs (Cheng et al., 2009; Lin et al., 2009). Overexpression of miR-21 results in decreased PDCD4 expression in $\mathrm{H}_{2} \mathrm{O}_{2}$ challenged VSMCs, and binding of miR-21 to PDCD4 was confirmed in vitro. Moreover, the miR-21 overexpression-mediated protective effect on VSMC apoptosis and death was blocked after forced overexpression of a PDCD4 construct lacking the miR-21 binding sites, suggesting that PDCD4 may act as a functional target gene of miR-21 (Lin et al., 2009). Another potential target gene of miR-21 is phosphatase and tensin homology deleted from chromosome 10 (PTEN) (Ji et al., 2007). PTEN is known to modulate cell survival/ apoptosis, hypertrophy and contractility (Oudit et al., 2004).

\section{Concluding remarks}

Understanding the miRNA expression profile in developing vessels is essential and invaluable for evaluating miRNAs biological functions. At present, expression profiles of miRNA in developing blood vessels are still incomplete. Large scale miRNA expression profiling in combination with loss- and gain-of-function screens in vivo, using zebrafish and target validation are feasible approaches to help understanding the full repertoire of action of miRNAs in angiogenesis and arteriogenesis. Furthermore, miRNAs play an important role in vascular adaptation to arterial occlusion, and adverse smooth muscle cell remodeling in the context of atherosclerosis, and vascular injury. In vivo studies in mice have shown that it is possible to therapeutically target miRNA function. Aptamers with miRNA modulators attached can be designed to bind to specific proteins that are readily internalized by endothelial cells or smooth muscle cells. It is expected that such approaches will yield therapeutic levels of miRNA drugs within the vascular target cells.

\section{Acknowledgements}

Dong Liu is a Ph.D student supported by a Graduate Scholarship Program from the China Scholarship Council (CSC). Janna Krueger is a Ph.D student supported by a grant from the BMBF - Center for Stroke research Berlin program (CSB).

\section{References}

ALBINSSON, S., SUAREZ, Y., SKOURA, A., OFFERMANNS, S., MIANO, J.M. and SESSA, W.C. (2010). MicroRNAs Are Necessary for Vascular Smooth Muscle Growth, Differentiation, and Function. Arterioscler Thromb Vasc Biol6: 1118-1126.

AMBROS, V. (2004). The functions of animal microRNAs. Nature 431: 350-355

BARTEL, D.P. (2004). MicroRNAs: genomics, biogenesis, mechanism, and function. Cell 116: 281-297.
BARTEL, D.P. and CHEN, C.Z. (2004). Micromanagers of gene expression: the potentially widespread influence of metazoan microRNAs. Nat Rev Genet 5: 396-400.

BASKERVILLE, S. and BARTEL, D.P. (2005). Microarray profiling of microRNAs reveals frequent coexpression with neighboring miRNAs and host genes. RNA 11: 241-247.

BEHM-ANSMANT, I., REHWINKEL, J., DOERKS, T., STARK, A., BORK, P. and IZAURRALDE, E. (2006). mRNA degradation by miRNAs and GW182 requires both CCR4:NOT deadenylase and DCP1:DCP2 decapping complexes. Genes Dev 20: 1885-1898.

BERNSTEIN, E., KIM, S.Y., CARMELL, M.A., MURCHISON, E.P., ALCORN, H., LI, M.Z., MILLS, A.A., ELLEDGE, S.J., ANDERSON, K.V. and HANNON, G.J. (2003). Dicer is essential for mouse development. Nat Genet 35: 215-217.

BOETTGER, T., BEETZ, N., KOSTIN, S., SCHNEIDER, J., KRUGER, M., HEIN, L. and BRAUN, T. (2009). Acquisition of the contractile phenotype by murine arterial smooth muscle cells depends on the Mir143/145 gene cluster. J Clin Invest 119: 2634-2647.

BONAUER, A., CARMONA, G., IWASAKI, M., MIONE, M., KOYANAGI, M., FISCHER, A., BURCHFIELD, J., FOX, H., DOEBELE, C., OHTANI, K. etal. (2009). MicroRNA$92 a$ controls angiogenesis and functional recovery of ischemic tissues in mice. Science 324: 1710-1713

BUSCHMANN, I., PRIES, A., STYP-REKOWSKA, B., HILLMEISTER, P., LOUFRANI, L., HENRION, D., SHI, Y., DUELSNER, A., HOEFER, I., GATZKE, N. et al. (2010). Pul-satile shear and Gja5 modulate arterial identity and remodeling events during flow-driven arteriogenesis. Development 137: 2187-2196.

CAI, X., HAGEDORN, C.H. and CULLEN, B.R. (2004). Human microRNAs are processed from capped, polyadenylated transcripts that can also function as mRNAs. RNA 10: 1957-1966.

CARMELIET, P. (2003). Angiogenesis in health and disease. Nat Med 9: 653-660.

CARTHEW, R.W. and SONTHEIMER, E.J. (2009). Origins and Mechanisms of miRNAs and siRNAs. Cell 136: 642-655.

CHAN, S.P. and SLACK, F.J. (2007). And now introducing mammalian mirtrons. Dev Cell 13: 605-607.

CHAPPELL, J.C., TAYLOR, S.M., FERRARA, N. and BAUTCH, V.L. (2009). Local guidance of emerging vessel sprouts requires soluble Flt-1. Dev Cell 17: 377-386.

CHEKULAEVA, M. and FILIPOWICZ, W. (2009). Mechanisms of miRNA-mediated post-transcriptional regulation in animal cells. Curr Opin Cell Biol 21: 452-460.

CHEN, D., KRASINSKI, K., SYLVESTER, A., CHEN, J., NISEN, P.D. and ANDRES, V. (1997). Downregulation of cyclin-dependent kinase 2 activity and cyclin A promoter activity in vascular smooth muscle cells by p27(KIP1), an inhibitor of neointima formation in the rat carotid artery. J Clin Invest 99: 2334-2341.

CHEN, J.F., MURCHISON, E.P., TANG, R., CALLIS, T.E., TATSUGUCHI, M., DENG, Z., ROJAS, M., HAMMOND, S.M., SCHNEIDER, M.D., SELZMAN, C.H. et al. (2008). Targeted deletion of Dicer in the heart leads to dilated cardiomyopathy and heart failure. Proc Natl Acad Sci USA 105: 2111-2116.

CHEN, Y. and GORSKI, D.H. (2008). Regulation of angiogenesis through a microRNA (miR-130a) that down-regulates antiangiogenic homeobox genes GAX and HOXA5. Blood 111: 1217-1226.

CHENG, Y., JI, R., YUE, J., YANG, J., LIU, X., CHEN, H., DEAN, D.B. and ZHANG, C. (2007). MicroRNAs are aberrantly expressed in hypertrophic heart: do they play a role in cardiac hypertrophy? Am J Pathol 170: 1831-1840.

CHENG, Y., LIU, X., YANG, J., LIN, Y., XU, D.Z., LU, Q., DEITCH, E.A., HUO, Y., DELPHIN, E.S. and ZHANG, C. (2009). MicroRNA-145, a novel smooth muscle cell phenotypic marker and modulator, controls vascular neointimal lesion formation. Circ Res 105: 158-166.

CORDES, K.R., SHEEHY, N.T., WHITE, M.P., BERRY, E.C., MORTON, S.U., MUTH A.N., LEE, T.H., MIANO, J.M., IVEY, K.N. and SRIVASTAVA, D. (2009). miR-145 and miR-143 regulate smooth muscle cell fate and plasticity. Nature 460:705-710.

COVASSIN, L.D., VILLEFRANC, J.A., KACERGIS, M.C., WEINSTEIN, B.M. and LAWSON, N.D. (2006). Distinct genetic interactions between multiple Vegf receptors are required for development of different blood vessel types in zebrafish. Proc Natl Acad Sci USA 103: 6554-6559.

DAVIS, B.N., HILYARD, A.C., NGUYEN, P.H., LAGNA, G. and HATA, A. (2009). Induction of microRNA-221 by platelet-derived growth factor signaling is critical for modulation of vascular smooth muscle phenotype. J Biol Chem 284: 3728-3738.

DE SMET, F., SEGURA, I., DE BOCK, K., HOHENSINNER, P.J. and CARMELIET, P. (2009). Mechanisms of vessel branching: filopodia on endothelial tip cells lead 
the way. Arterioscler Thromb Vasc Biol 29: 639-649.

DEWS, M., HOMAYOUNI, A., YU, D., MURPHY, D., SEVIGNANI, C., WENTZEL, E., FURTH, E.E., LEE, W.M., ENDERS, G.H., MENDELL, J.T. et al. (2006). Augmentation of tumor angiogenesis by a Myc-activated microRNA cluster. Nat Genet 38: 1060-1065

DJONOV, V., BAUM, O. and BURRI, P.H. (2003). Vascular remodeling by intussusceptive angiogenesis. Cell Tissue Res 314: 107-117.

DJONOV, V., SCHMID, M., TSCHANZ, S.A. and BURRI, P.H. (2000). Intussusceptive angiogenesis: its role in embryonic vascular network formation. Circ Res 86: 286-292.

DOEBELE, C., BONAUER, A., FISCHER, A., SCHOLZ, A., REISS, Y., URBICH, C., HOFMANN, W.K., ZEIHER, A.M. and DIMMELER, S. (2010). Members of the microRNA-17-92 cluster exhibit a cell intrinsic anti-angiogenic function in endothelial cells. Blood 23: 4944-4950.

DOENCH, J.G., PETERSEN, C.P. and SHARP, P.A. (2003). siRNAs can function as miRNAs. Genes Dev 17: 438-442.

DORAN, A.C., MELLER, N. and MCNAMARA, C.A. (2008). Role of smooth muscle cells in the initiation and early progression of atherosclerosis. Arterioscler Thromb Vasc Biol 28: 812-819.

EITENMULLER, I., VOLGER, O., KLUGE, A., TROIDL, K., BARANCIK, M., CAI, W.J., HEIL, M., PIPP, F., FISCHER, S., HORREVOETS, A.J. et al. (2006). The range of adaptation by collateral vessels after femoral artery occlusion. Circ Res 99:656-662.

EULALIO, A., HUNTZINGER, E. and IZAURRALDE, E. (2008). Getting to the root of miRNA-mediated gene silencing. Cell 132: 9-14.

FALLER, M. and GUO, F. (2008). MicroRNA biogenesis: there's more than one way to skin a cat. Biochim Biophys Acta 1779: 663-667.

FASANARO, P., D'ALESSANDRA, Y., DISTEFANO, V., MELCHIONNA, R., ROMANI, S., POMPILIO, G., CAPOGROSSI, M.C. and MARTELLI, F. (2008). MicroRNA-210 modulates endothelial cell response to hypoxia and inhibits the receptor tyrosine kinase ligand Ephrin-A3. J Biol Chem 283: 15878-15883.

FELICETTI, F., ERRICO, M.C., BOTTERO, L., SEGNALINI, P., STOPPACCIARO, A., BIFFONI, M., FELLI, N., MATTIA, G., PETRINI, M., COLOMBO, M.P. et al. (2008). The promyelocytic leukemia zinc finger-microRNA-221/-222 pathway controls melanoma progression through multiple oncogenic mechanisms. Cancer Res 68: 2745-2754

FELLI, N., FONTANA, L., PELOSI, E., BOTTA, R., BONCI, D., FACCHIANO, F., LIUZZI, F., LULLI, V., MORSILLI, O., SANTORO, S. et al. (2005). MicroRNAs 221 and 222 inhibit normal erythropoiesis and erythroleukemic cell growth via kit receptor down-modulation. Proc Natl Acad Sci USA 102: 18081-18086.

FISH, J.E., SANTORO, M.M., MORTON, S.U., YU, S., YEH, R.F., WYTHE, J.D., IVEY, K.N., BRUNEAU, B.G., STAINIER, D.Y. and SRIVASTAVA, D. (2008). miR126 regulates angiogenic signaling and vascular integrity. Dev Cell 15: 272-284.

FORNARI, F., GRAMANTIERI, L., FERRACIN, M., VERONESE, A., SABBIONI, S., CALIN, G.A., GRAZI, G.L., GIOVANNINI, C., CROCE, C.M., BOLONDI, L. et al. (2008). MiR-221 controls CDKN1C/p57 and CDKN1B/p27 expression in human hepatocellular carcinoma. Oncogene 27: 5651-5661.

GALARDI, S., MERCATELLI, N., GIORDA, E., MASSALINI, S., FRAJESE, G.V., CIAFRE, S.A. and FARACE, M.G. (2007). miR-221 and miR-222 expression affects the proliferation potential of human prostate carcinoma cell lines by targeting p27Kip1. J Biol Chem 282: 23716-23724.

GERHARDT, H., GOLDING, M., FRUTTIGER, M., RUHRBERG, C., LUNDKVIST, A., ABRAMSSON, A., JELTSCH, M., MITCHELL, C., ALITALO, K., SHIMA, D. et al. (2003). VEGF guides angiogenic sprouting utilizing endothelial tip cell filopodia. J Cell Biol 161: 1163-1177.

GIRALDEZ, A.J., CINALLI, R.M., GLASNER, M.E., ENRIGHT, A.J., THOMSON, J.M., BASKERVILLE, S., HAMMOND, S.M., BARTEL, D.P. and SCHIER, A.F. (2005). MicroRNAs regulate brain morphogenesis in zebrafish. Science 308: 833-838.

GIRALDEZ, A.J., MISHIMA, Y., RIHEL, J., GROCOCK, R.J., VAN DONGEN, S., INOUE, K., ENRIGHT, A.J. and SCHIER, A.F. (2006). Zebrafish MiR-430 promotes deadenylation and clearance of maternal mRNAs. Science 312: 75-79.

GRAY, C., PACKHAM, I.M., WURMSER, F., EASTLEY, N.C., HELLEWELL, P.G., INGHAM, P.W., CROSSMAN, D.C. and CHICO, T.J. (2007). Ischemia is not required for arteriogenesis in zebrafish embryos. Arterioscler Thromb Vasc Biol 27: $2135-2141$

GRIDLEY, T. (2007). Notch signaling in vascular development and physiology. Development 134: 2709-2718.
HARFE, B.D., MCMANUS, M.T., MANSFIELD, J.H., HORNSTEIN, E. and TABIN C.J. (2005). The RNaselll enzyme Dicer is required for morphogenesis but not patterning of the vertebrate limb. Proc Natl Acad Sci USA 102: 10898-10903.

HARRIS, T.A., YAMAKUCHI, M., FERLITO, M., MENDELL, J.T. and LOWENSTEIN, C.J. (2008). MicroRNA-126 regulates endothelial expression of vascular cell adhesion molecule 1. Proc Natl Acad Sci USA 105: 1516-1521.

HE, S., SU, H., LIU, C., SKOGERBO, G., HE, H., HE, D., ZHU, X., LIU, T., ZHAO, Y. and CHEN, R. (2008). MicroRNA-encoding long non-coding RNAs. BMC Genomics 9: 236.

HELLSTROM, M., PHNG, L.K., HOFMANN, J.J., WALLGARD, E., COULTAS, L., LINDBLOM, P., ALVA, J., NILSSON, A.K., KARLSSON, L., GAIANO, N. et al. (2007). Dll4 signalling through Notch1 regulates formation of tip cells during angiogenesis. Nature 445: 776-780.

HUA, Z., LV, Q., YE, W., WONG, C.K., CAI, G., GU, D., JI, Y., ZHAO, C., WANG, J., YANG, B.B. etal. (2006). MiRNA-directed regulation of VEGF and other angiogenic factors under hypoxia. PLoS One 1: e116.

HWANG, H.W. and MENDELL, J.T. (2006). MicroRNAs in cell proliferation, cell death and tumorigenesis. Br J Cancer 94: 776-780.

IVAN, M., HARRIS, A.L., MARTELLI, F. and KULSHRESHTHA, R. (2008). Hypoxia response and microRNAs: no longer two separate worlds. J Cell Mol Med 12 1426-1431.

JI, R., CHENG, Y., YUE, J., YANG, J., LIU, X., CHEN, H., DEAN, D.B. and ZHANG, C. (2007). MicroRNA expression signature and antisense-mediated depletion reveal an essential role of MicroRNA in vascular neointimal lesion formation Circ Res 100: 1579-1588.

JIANG, J., LEE, E.J., GUSEV, Y. and SCHMITTGEN, T.D. (2005). Real-time expression profiling of microRNA precursors in human cancer cell lines. Nucleic Acids Res 33: 5394-5403.

JONES, E.A., YUAN, L., BREANT, C., WATTS, R.J. and EICHMANN, A. (2008). Separating genetic and hemodynamic defects in neuropilin 1 knockout embryos. Development 135: 2479-2488.

JOVANOVIC, M. and HENGARTNER, M.O. (2006). miRNAs and apoptosis: RNAs to die for. Oncogene 25: 6176-87.

KIM, Y.K. and KIM, V.N. (2007). Processing of intronic microRNAs. EMBO J26:775-783

KLOOSTERMAN, W.P. and PLASTERK, R.H. (2006). The diverse functions of microRNAs in animal development and disease. Dev Cell 11: 441-450.

KUEHBACHER, A., URBICH, C., ZEIHER, A.M. and DIMMELER, S. (2007). Role of Dicer and Drosha for endothelial microRNA expression and angiogenesis. Circ Res 101: 59-68.

KUHNERT, F., MANCUSO, M.R., HAMPTON, J., STANKUNAS, K., ASANO, T., CHEN, C.Z. and KUO, C.J. (2008). Attribution of vascular phenotypes of the murine Egfl7 locus to the microRNA miR-126. Development 135: 3989-3993.

LAGOS-QUINTANA, M., RAUHUT, R., LENDECKEL, W. and TUSCHL, T. (2001). Identification of novel genes coding for small expressed RNAs. Science 294: 853-858

LAGOS-QUINTANA, M., RAUHUT, R., YALCIN, A., MEYER, J., LENDECKEL, W. and TUSCHL, T. (2002). Identification of tissue-specific microRNAs from mouse. Curr Biol 12: 735-739.

LARRIVEE, B., FREITAS, C., SUCHTING, S., BRUNET, I. and EICHMANN, A. (2009). Guidance of vascular development: lessons from the nervous system. Circ Res 104: 428-441.

LAU, N.C., LIM, L.P., WEINSTEIN, E.G. and BARTEL, D.P. (2001). An abundant class of tiny RNAs with probable regulatory roles in Caenorhabditis elegans. Science 294: 858-862.

LAWSON, N.D., VOGEL, A.M. and WEINSTEIN, B.M. (2002). sonic hedgehog and vascular endothelial growth factor act upstream of the Notch pathway during arterial endothelial differentiation. Dev Cell 3: 127-136.

LE NOBLE, F., MOYON, D., PARDANAUD, L., YUAN, L., DJONOV, V., MATTHIJSEN, R., BREANT, C., FLEURY, V. and EICHMANN, A. (2004). Flow regulates arterialvenous differentiation in the chick embryo yolk sac. Development 131: 361-375.

LE SAGE, C., NAGEL, R., EGAN, D.A., SCHRIER, M., MESMAN, E., MANGIOLA, A. ANILE, C., MAIRA, G., MERCATELLI, N., CIAFRE, S.A. et al. (2007). Regulation of the p27(Kip1) tumor suppressor by miR-221 and miR-222 promotes cancer cell proliferation. EMBO J 26: 3699-3708.

LEE, D.Y., DENG, Z., WANG, C.H. and YANG, B.B. (2007). MicroRNA-378 promotes cell survival, tumor growth, and angiogenesis by targeting SuFu and Fus-1 expres- 
sion. Proc Natl Acad Sci USA 104: 20350-20355.

LEE, R.C. and AMBROS, V. (2001). An extensive class of small RNAs in Caenorhabditis elegans. Science 294: 862-864.

LEE, R.C., FEINBAUM, R.L. and AMBROS, V. (1993). The C. elegans heterochronic gene lin-4 encodes small RNAs with antisense complementarity to lin-14. Cell 75: 843-854.

LEE, Y., KIM, M., HAN, J., YEOM, K.H., LEE, S., BAEK, S.H. and KIM, V.N. (2004). MicroRNA genes are transcribed by RNA polymerase II. EMBO J 23: 4051-4060.

LIN, Y., LIU, X., CHENG, Y., YANG, J., HUO, Y. and ZHANG, C. (2009). Involvement of MicroRNAs in hydrogen peroxide-mediated gene regulation and cellular injury response in vascular smooth muscle cells. J Biol Chem 284: 7903-7913.

LIU, X., CHENG, Y., ZHANG, S., LIN, Y., YANG, J. and ZHANG, C. (2009). A necessary role of miR-221 and miR-222 in vascular smooth muscle cell proliferation and neointimal hyperplasia. Circ Res 104: 476-487.

LUCITTI, J.L., JONES, E.A., HUANG, C., CHEN, J., FRASER, S.E. and DICKINSON, M.E. (2007). Vascular remodeling of the mouse yolk sac requires hemodynamic force. Development 134: 3317-3326.

MENDELL, J.T. (2008). miRiad roles for the miR-17-92 cluster in development and disease. Cell 133: 217-222.

MINAMI, Y., SATOH, M., MAESAWA, C., TAKAHASHI, Y., TABUCHI, T., ITOH, T. and NAKAMURA, M. (2009). Effect of atorvastatin on microRNA 221 / 222 expression in endothelial progenitor cells obtained from patients with coronary artery disease. Eur J Clin Invest 39: 359-367.

MUROHARA, T., ASAHARA, T., SILVER, M., BAUTERS, C., MASUDA, H., KALKA, C., KEARNEY, M., CHEN, D., SYMES, J.F., FISHMAN, M.C. et al. (1998). Nitric oxide synthase modulates angiogenesis in response to tissue ischemia. J Clin Invest 101: 2567-2578.

NAGAI, R., SUZUKI, T., AIZAWA, K., SHINDO, T. and MANABE, I. (2005). Significance of the transcription factor KLF5 in cardiovascular remodeling. $J$ Thromb Haemost 3: 1569-1576.

NICOLI, S., STANDLEY, C., WALKER, P., HURLSTONE, A., FOGARTY, K.E. and LAWSON, N.D. (2010). MicroRNA-mediated integration of haemodynamics and Vegf signalling during angiogenesis. Nature 464: 1196-1200.

OLIVE, V., JIANG, I. and HE, L. (2010). miR-17-92, a cluster of miRNAs in the midst of the cancer network. Int J Biochem Cell Biol 8: 1345-1354.

OUDIT, G.Y., SUN, H., KERFANT, B.G., CRACKOWER, M.A., PENNINGER, J.M. and BACKX, P.H. (2004). The role of phosphoinositide-3 kinase and PTEN in cardiovascular physiology and disease. J Mol Cell Cardiol 37: 449-471.

OWENS, G.K., KUMAR, M.S. and WAMHOFF, B.R. (2004). Molecular regulation of vascular smooth muscle cell differentiation in development and disease. Physiol Rev 84: 767-801.

PHNG, L.K., POTENTE, M., LESLIE, J.D., BABBAGE, J., NYQVIST, D., LOBOV, I., ONDR, J.K., RAO, S., LANG, R.A., THURSTON, G. etal. (2009). Nrarp coordinates endothelial Notch and Wnt signaling to control vessel density in angiogenesis. Dev Cell 16: 70-82.

POLISENO, L., TUCCOLI, A., MARIANI, L., EVANGELISTA, M., CITTI, L., WOODS, K., MERCATANTI, A., HAMMOND, S. and RAINALDI, G. (2006). MicroRNAs modulate the angiogenic properties of HUVECs. Blood 108: 3068-3071.

PULKKINEN, K., MALM, T., TURUNEN, M., KOISTINAHO, J. and YLA-HERTTUALA S. (2008). Hypoxia induces microRNA miR-210 in vitro and in vivo ephrin-A3 and neuronal pentraxin 1 are potentially regulated by miR-210. FEBS Lett 582: 2397-2401.

RODRIGUEZ, A., GRIFFITHS-JONES, S., ASHURST, J.L. and BRADLEY, A. (2004). Identification of mammalian microRNA host genes and transcription units. Genome Res 14: 1902-1910

ROY, S., KHANNA, S., HUSSAIN, S.R., BISWAS, S., AZAD, A., RINK, C., GNYAWALI, S., SHILO, S., NUOVO, G.J. and SEN, C.K. (2009). MicroRNA expression in response to murine myocardial infarction: miR-21 regulates fibroblast metalloprotease-2 via phosphatase and tensin homologue. Cardiovasc Res 82: 21-29.

RUHRBERG, C., GERHARDT, H., GOLDING, M., WATSON, R., IOANNIDOU, S., FUJISAWA, H., BETSHOLTZ, C. and SHIMA, D.T. (2002). Spatially restricted patterning cues provided by heparin-binding VEGF-A control blood vessel branching morphogenesis. Genes Dev 16: 2684-2698.

RZUCIDLO, E.M., MARTIN, K.A. and POWELL, R.J. (2007). Regulation of vascular smooth muscle cell differentiation. J Vasc Surg 45 Suppl A: A25-32.
SARAIYA, A.A. and WANG, C.C. (2008). snoRNA, a novel precursor of microRNA in Giardia lamblia. PLoS Pathog 4: e1000224.

SCHAPER, W. (2009). Collateral circulation: past and present. Basic Res Cardiol 104: 5-21.

SHILO, S., ROY, S., KHANNA, S. and SEN, C.K. (2008). Evidence for the involvement of miRNA in redox regulated angiogenic response of human microvascular endothelial cells. Arterioscler Thromb Vasc Biol 28: 471-477.

SIEKMANN, A.F. and LAWSON, N.D. (2007). Notch signalling limits angiogenic cell behaviour in developing zebrafish arteries. Nature 445: 781-784.

STEFANI, G. and SLACK, F.J. (2008). Small non-coding RNAs in animal development. Nat Rev Mol Cell Biol 9: 219-230.

SUAREZ, Y., FERNANDEZ-HERNANDO, C., POBER, J.S. and SESSA, W.C. (2007) Dicer dependent microRNAs regulate gene expression and functions in human endothelial cells. Circ Res 100: 1164-1173.

SUAREZ, Y., FERNANDEZ-HERNANDO, C., YU, J., GERBER, S.A., HARRISON, K.D., POBER, J.S., IRUELA-ARISPE, M.L., MERKENSCHLAGER, M. and SESSA, W.C. (2008). Dicer-dependent endothelial microRNAs are necessary for postnatal angiogenesis. Proc Natl Acad Sci USA 105: 14082-14087.

SUCHTING, S., FREITAS, C., LE NOBLE, F., BENEDITO, R., BREANT, C., DUARTE, A. and EICHMANN, A. (2007). The Notch ligand Delta-like 4 negatively regulates endothelial tip cell formation and vessel branching. Proc Natl Acad Sci USA 104: 3225-3230.

SWIFT, M.R. and WEINSTEIN, B.M. (2009). Arterial-venous specification during development. Circ Res 104: 576-588.

TAGUCHI, A., YANAGISAWA, K., TANAKA, M., CAO, K., MATSUYAMA, Y., GOTO, $\mathrm{H}$. and TAKAHASHI, T. (2008). Identification of hypoxia-inducible factor-1 alpha as a novel target for miR-17-92 microRNA cluster. Cancer Res 68: 5540-5545.

TAMMELA, T., ZARKADA, G., WALLGARD, E., MURTOMAKI, A., SUCHTING, S., WIRZENIUS, M., WALTARI, M., HELLSTROM, M., SCHOMBER, T., PELTONEN, R. etal. (2008). Blocking VEGFR-3 suppresses angiogenic sprouting and vascular network formation. Nature 454: 656-660.

TINTU, A., ROUWET, E., VERLOHREN, S., BRINKMANN, J., AHMAD, S., CRISPI, F., VAN BILSEN, M., CARMELIET, P., STAFF, A.C., TJWA, M. et al. (2009). Hypoxia induces dilated cardiomyopathy in the chick embryo: mechanism, intervention, and long-term consequences. PLoS One 4: e5155.

VAN ROOIJ, E., SUTHERLAND, L.B., LIU, N., WILLIAMS, A.H., MCANALLY, J., GERARD, R.D., RICHARDSON, J.A. and OLSON, E.N. (2006). A signature pattern of stress-responsive microRNAs that can evoke cardiac hypertrophy and heart failure. Proc Natl Acad Sci USA 103: 18255-18260.

VAN SOLINGEN, C., SEGHERS, L., BIJKERK, R., DUIJS, J.M., ROETEN, M.K., VAN OEVEREN-RIETDIJK, A.M., BAELDE, H.J., MONGE, M., VOS, J.B., DE BOER, H.C. et al. (2009). AntagomiR-mediated silencing of endothelial cell specific microRNA-126 impairs ischemia-induced angiogenesis. J Cell Mol Med 13: 1577-1585.

VANDENBROUCKE, K., ROBBENS, S., VANDEPOELE, K., INZE, D., VAN DE PEER, Y. and VAN BREUSEGEM, F. (2008). Hydrogen peroxide-induced gene expression across kingdoms: a comparative analysis. Mol Biol Evol 25: 507-516.

VISONE, R., PALLANTE, P., VECCHIONE, A., CIROMBELLA, R., FERRACIN, M., FERRARO, A., VOLINIA, S., COLUZZI, S., LEONE, V., BORBONE, E. etal. (2007). Specific microRNAs are downregulated in human thyroid anaplastic carcinomas. Oncogene 26: 7590-7595.

WANG, C., HAN, M., ZHAO, X.M. and WEN, J.K. (2008a). Kruppel-like factor 4 is required for the expression of vascular smooth muscle cell differentiation marker genes induced by all-trans retinoic acid. J Biochem 144: 313-321.

WANG, S., AURORA, A.B., JOHNSON, B.A., QI, X., MCANALLY, J., HILL, J.A. RICHARDSON, J.A., BASSEL-DUBY, R. and OLSON, E.N. (2008b). The endothelial-specific microRNA miR-126 governs vascular integrity and angiogenesis. Dev Cell 15: 261-271.

WANG, X.H., QIAN, R.Z., ZHANG, W., CHEN, S.F., JIN, H.M. and HU, R.M. (2009) MicroRNA-320 expression in myocardial microvascular endothelial cells and its relationship with insulin-like growth factor-1 in type 2 diabetic rats. Clin Exp Pharmacol Physiol 36: 181-188.

WEBER, M.J. (2005). New human and mouse microRNA genes found by homology search. FEBS J 272: 59-73.

WIENHOLDS, E., KLOOSTERMAN, W.P., MISKA, E., ALVAREZ-SAAVEDRA, E., BEREZIKOV, E., DE BRUIJN, E., HORVITZ, H.R., KAUPPINEN, S. and PLAS- 
TERK, R.H. (2005). MicroRNA expression in zebrafish embryonic development. Science 309: 310-311.

WIENHOLDS, E., KOUDIJS, M.J., VAN EEDEN, F.J., CUPPEN, E. and PLASTERK, R.H. (2003). The microRNA-producing enzyme Dicer1 is essential for zebrafish development. Nat Genet 35: 217-218.

WIGHTMAN, B., HA, I. and RUVKUN, G. (1993). Posttranscriptional regulation of the heterochronic gene lin-14 by lin-4 mediates temporal pattern formation in C. elegans. Cell 75: 855-862.

WURDINGER, T., TANNOUS, B.A., SAYDAM, O., SKOG, J., GRAU, S., SOUTSCHEK, J., WEISSLEDER, R., BREAKEFIELD, X.O. and KRICHEVSKY, A.M. (2008). miR-296 regulates growth factor receptor overexpression in angiogenic endothelial cells. Cancer Cell 14: 382-393.
XIN, M., SMALL, E.M., SUTHERLAND, L.B., QI, X., MCANALLY, J., PLATO, C.F., RICHARDSON, J.A., BASSEL-DUBY, R. and OLSON, E.N. (2009). MicroRNAs miR-143 and miR-145 modulate cytoskeletal dynamics and responsiveness of smooth muscle cells to injury. Genes Dev 23: 2166-2178.

YANG, W.J., YANG, D.D., NA, S., SANDUSKY, G.E., ZHANG, Q. and ZHAO, G. (2005). Dicer is required for embryonic angiogenesis during mouse development. J Biol Chem 280: 9330-9335.

YEKTA, S., TABIN, C.J. and BARTEL, D.P. (2008). MicroRNAs in the Hox network: an apparent link to posterior prevalence. Nat Rev Genet 9: 789-796.

YOSHIDA, T., KAESTNER, K.H. and OWENS, G.K. (2008). Conditional deletion of Kruppellike factor 4 delays downregulation of smooth muscle cell differentiation markers but accelerates neointimal formation following vascular injury. Circ Res 102: 1548-1557. 


\section{Further Related Reading, published previously in the Int. J. Dev. Biol.}

The role of pericytes in angiogenesis

Domenico Ribatti, Beatrice Nico and Enrico Crivellato

Int. J. Dev. Biol. (2011) 55: 261-268

Shear stress regulation of nitric oxide production in uterine and placental artery endothelial cells: experimental studies and hemodynamic models of shear stresses on endothelial cells

Benjamin Sprague, Naomi C. Chesler and Ronald R. Magness

Int. J. Dev. Biol. (2010) 54: 331-339

Embryonic development of the proepicardium and coronary vessels

Anna Ratajska, Elzbieta Czarnowska and Bogdan Ciszek.

Int. J. Dev. Biol. (2008) 52: 229-236

Vasculogenesis and angiogenesis in the mouse embryo studied using quail/mouse chimeras Michel Pudliszewski and Luc Pardanaud

Int. J. Dev. Biol. (2005) 49: 355-361

Vascular development: from precursor cells to branched arterial and venous networks

Anne Eichmann, Li Yuan, Delphine Moyon, Ferdinand le Noble, Luc Pardanaud and Christiane Bréant.

Int. J. Dev. Biol. (2005) 49: 259-267

Pathways in blood and vessel development revealed through zebrafish genetics

Philip S Crosier, Maggie L Kalev-Zylinska, Christopher J Hall, Maria Vega C Flores, Julia A Horsfield and Kathryn E Crosier.

Int. J. Dev. Biol. (2002) 46: 493-502

The chick embryo chorioallantoic membrane as a model for in vivo research on angiogenesis

D Ribatti, A Vacca, L Roncali and F Dammacco

Int. J. Dev. Biol. (1996) 40: 1189-1197

5 yr ISI Impact Factor $(2009)=3.253$
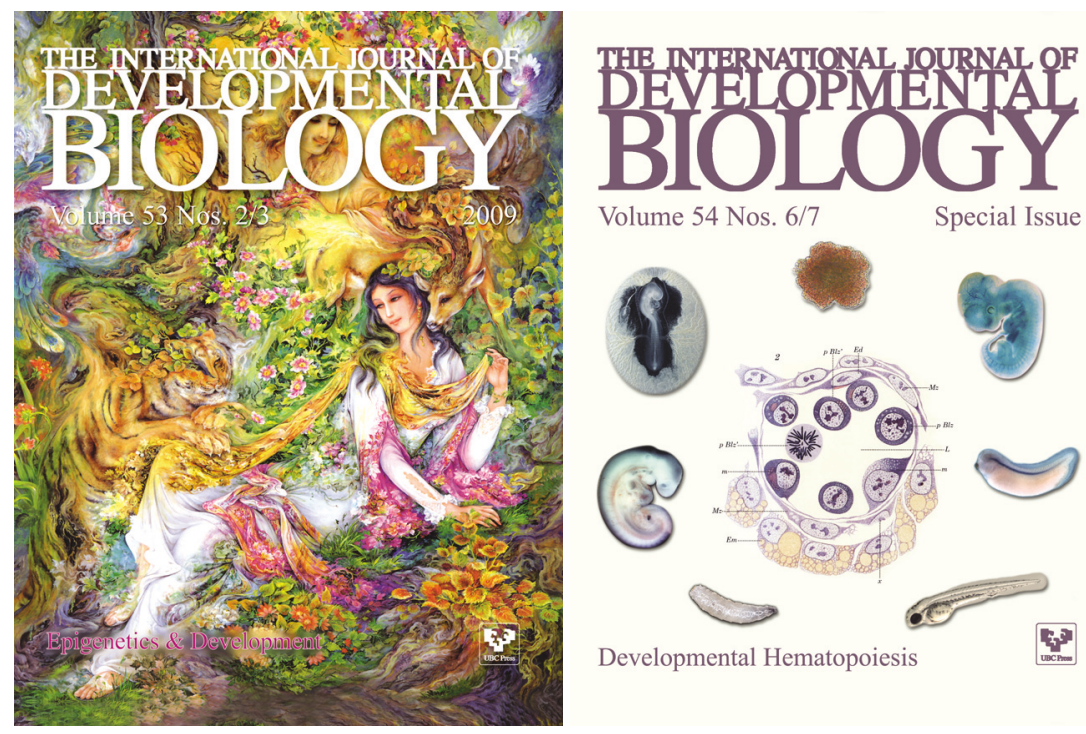

Volume 54 Nos. $6 / 7$

Special Issue
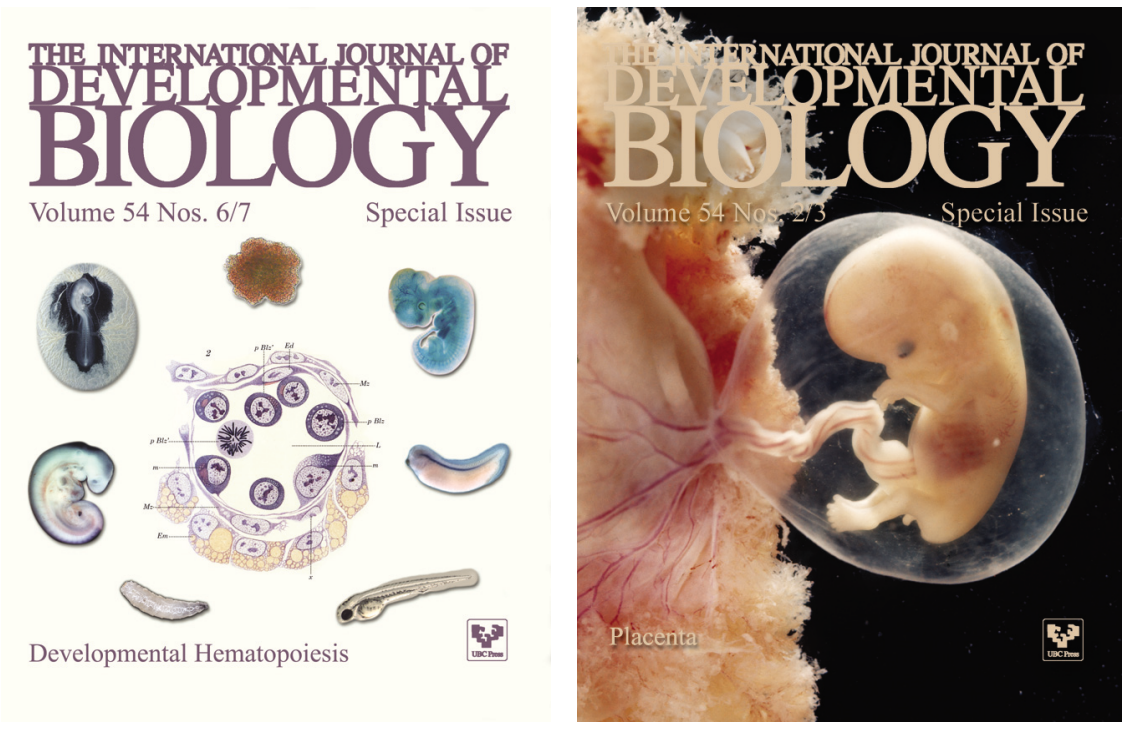